\title{
Phycodes templus isp. nov. from the Lower Devonian of northwestern New Brunswick, eastern Canada
}

\author{
Yaojun Han and Ron K. Pickerill \\ Department of Geology, University of New Brunswick, Fredericton, New Brunswick E3B 5A3, Canada
}

Date Received 26 November 1993
Date Accepted 15 February 1994

\begin{abstract}
Phycodes templus isp. nov. is described from siliciclastic turbidites of the Wapske Formation of the Tobique Group (Lower Devonian) of northwestern New Brunswick, eastern Canada. The new ichnospecies is characterized by a minimum of two, more typically several, bundled sets of essentially horizontal, broomlike or flabellate, internally structureless, lined burrows. Burrow sets within an individual specimen are interconnected by a single tunnel to form an overall inverted pagodashaped structure. The ichnotaxon is believed to have been produced by a vagile deposit feeder, most likely a worm-like organism.
\end{abstract}

Phycodes templus isp. nov. est décrit à partir d'échantillons provenant de turbidites siliciclastiques de la Formation de Wapske du Groupe de Tobique (Dévonien inférieur) du nord-ouest du Nouveau-Brunswick, dans l'Est du Canada. La nouvelle espèce d'ichnofossile est caractérisée par un minimum de deux, plus typiquement plusieurs ensembles groupés de terriers doublés, essentiellement horizontaux, en forme de balai ou d'éventail et sans structures internes. Les ensembles de terriers dans un spécimen donné sont interconnectés par un tunnel simple pour former une structure d'ensemble en forme de pagode inversée. On croît que l'ichnofossile a été produit par un animal mobile se nourissant de dépôts et ressemblant probablement à un ver.

[Traduit par la rédaction]

\section{INTRODUCTION}

Phycodes Richter, 1850 is a relatively common and widely reported ichnotaxon from Phanerozoic shallow and, less commonly, deep-marine and non-marine environments. The ichnogenus is characterized by essentially horizontal bundled structures of typically flabellate or broomlike burrows that are developed from a single or a few initial (or proximal) tunnels. Such proximal tunnels may or may not possess a spreite. Existing ichnospecies of Phycodes are distinguished largely on the nature, style, disposition and degree of burrowing from the initial proximal structures. Ichnological analysis of the Lower Devonian Wapske Formation, northwestern New Brunswick, eastern Canada, has revealed a quite different style of burrowing to that present in existing ichnospecies of Phycodes. The purpose of this short contribution is, therefore, to describe this material and, in doing so, to formulate a new ichnospecies, Phycodes templus.

\section{LOCATION, STRATIGRAPHY AND GEOLOGICAL SETTING}

Specimens described herein are from the Lower Devonian (Helderbergian) Wapske Formation of the Tobique Group of the Riley Brook-Nictau area of northwestern New Brunswick, eastern Canada (Fig. 1). The Wapske Formation, approximately 6 to $9 \mathrm{~km}$ thick, is the uppermost formation of the conformably overlying, and partly laterally equivalent, basal Costigan Mountain Formation, approximately $3 \mathrm{~km}$ thick, of the Tobique Group (St. Peter, 1978; Dostal et al., 1989). In the Riley Brook-Nictau area, the Wapske Formation consists of an essentially siliciclastic sedimentary sequence interbedded with decreased proportions of volcanic strata. Pickerill $(1986,1991)$ and Wilson (1990) have interpreted the depositional environment as deep-marine in origin.

Siliciclastic strata comprise thinly bedded $(2-6 \mathrm{~cm})$ and medium bedded $(8-20 \mathrm{~cm}$, commonly $4-8 \mathrm{~cm})$ grey, greenishgrey, brown or maroon siltstones and fine-grained sandstones interbedded with 1 to $5 \mathrm{~cm}$ thick (commonly $2 \mathrm{~cm}$ ) shales or mudstones. Studies of coeval strata to the southwest of the Riley Brook-Nictau area (St. Peter, 1978, 1979; Pickerill, 1986; Wilson, 1990) suggest that the Wapske Formation is a relatively deep-water turbiditic sequence deposited below storm wave base. Siltstones and fine-grained sandstones exposed in the Riley Brook-Nictau area commonly show partial Bouma sequences, particularly $\mathrm{Tb}, \mathrm{Tb}-\mathrm{c}$ and $\mathrm{Tb}-\mathrm{d}$, and therefore a similar palaeoenvironmental interpretation is not unreasonable.

The material described herein was collected from four roadcut sections along Route 385 that runs parallel to the Mamozekel River, just southwest and northeast of the confluence of the Serpentine River logging road and Route 385 (Fig. 1). At these locations, associated ichnotaxa include $A$ rthraria Billings, Bergaueria Prantl, Chondrites von Sternberg, Helminthopsis Heer, Neonereites Seilacher, Palaeophycus Hall, Phycodes Richter, Rusophycus Hall, and Uchirites Macsotay.

\section{SYSTEMATIC ICHNOLOGY}

\section{Ichnogenus Phycodes Richter, 1850}

Type ichnospecies: Phycodes circinatus Richter, 1853 by subsequent monotypy. 


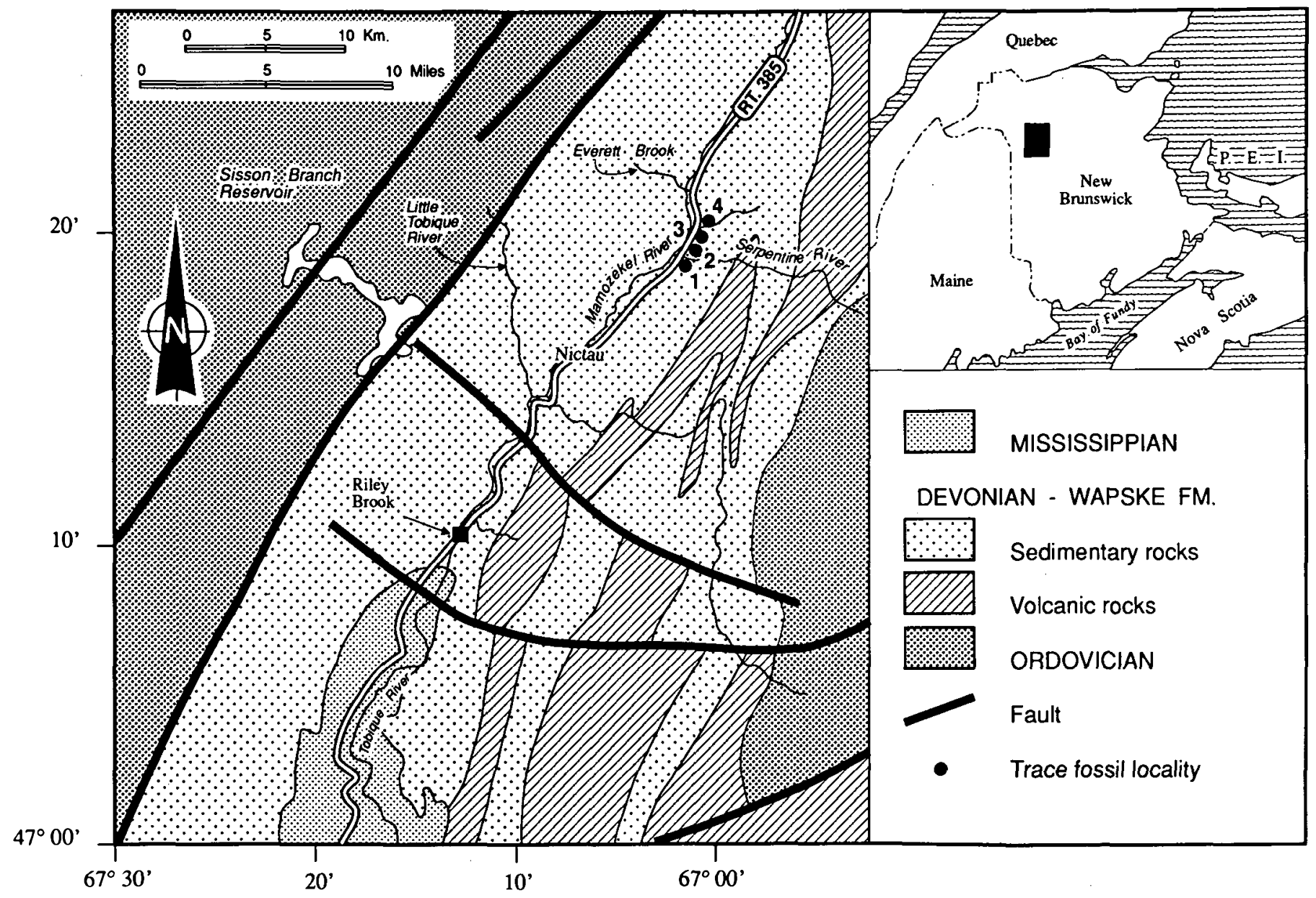

Fig. 1. Simplified geological map of the Riley Brook-Nictau area of northwestern New Brunswick, indicating locations of collected specimens of Phycodes templus.

Diagnosis: Horizontally bundled burrows preserved outwardly as convex hyporeliefs. Overall pattern reniform, fasciculate, flabellate, broomlike, ungulate, linear, falcate or circular. Most forms consist of a single or a few main branches showing a spreite-like structure that give rise distally to numerous free branches. In other forms the spreiten are lacking and branching tends to be secund or more random. Individual branches are terete and finely annulate or smooth (after Osgood, 1970; Fillion and Pickerill, 1990).

Discussion: Richter (1850) established Phycodes and later (Richter, 1853) erected $P$. circinnatum, which is now regarded as the nomenclatural type of the ichnogenus by subsequent monotypy. There has been considerable confusion regarding the correct spelling of the type ichnospecies of Phycodes since Mägdefrau (1934) attempted to revise the original orthographic error made by Richter (1853) by simply modifying the name to $P$. circinatum. Mägdefrau (1934) regarded Phycodes as neuter. However, as ichnogeneric names ending in -odes must be considered masculine (ICZN, Article 30b), the correct spclling of this ichnospecies is Phycodes circinatus. A more detailed discussion on the orthographic history of $P$. circinatus is given in Fillion and Pickerill (1990).

Phycodes has been extensively discussed by Mägdefrau (1934), Seilacher (1955), Osgood (1970), Bradley $(1980,1981)$ and Fillion and Pickerill (1990). The structure was originally regarded as a "fucoid" (plant) or an "inorganic structure" (Richter, 1850). However, more detailed studies by these and other authors have shown conclusively that it represents a branching burrow system. The producer has been considered to be a sediment-feeding vermiform annelid (Seilacher, 1955; Häntzschel, 1975), a Pennatulacean (Bradley, 1980), or anthoptiloid sea pen (Bradley, 1981).

Ethologically, two explanations for the origin of the structure have been proposed. Seilacher (1955) considered Phycodes a fodinichnion produced by an organism systematically mining a nutrient-rich layer along a silt-mud interface. He proposed that the producing-animal first burrowed down through silt, then moved horizontally in a manner producing a " $U$ "-shaped structure in which one limb was steeper than the other. Following this, the organism withdrew from the distal portion of the burrow and proceeded to excavate a new tunnel adjacent to the previously formed one. Periodically the unbranched proximal portion of the burrow was elevated by removing sediment from the ceiling and packing it, along with waste material, on the floor. This activity gave rise to a retrusive spreite-like structure. When a given area was mined out, a new "master" tunnel was formed at a separate location, and the entire process repeated again. Alternatively, however, Marintsch and Finks (1982) suggested that Phycodes may have been formed by an organism that burrowed outwards from a single point and then withdrew to a "home base" only to re-burrow outwards again, following 
in part the previously excavated tunnel perhaps as a guide. After complete divergence, the organism subsequently returned to "home base" in order to once again repeat the cycle.

Unlike the suggestion of Seilacher (1955), the material described herein does not possess spreiten in the unbranched proximal burrows. We therefore infer that elevation of these proximal portions was not an active process. Like the suggestion of Marintsch and Finks (1982), however, we believe that in $P$. templus burrowing was initiated from a "home base" followed by withdrawl and then by thigmotaxic horizontal burrowing. Subsequently, however, the producing organism moved fonvard to establish an interconnected but new "home base" or "master" tunnel to repeat a similar burrowing process. Ethologically, therefore, our material appears to reflect elements of both Seilacher's (1955) and Marintsch and Finks' (1982) explanations. Clearly, a variety of behavioural activities may well be responsible for the production of Phycodes and individual examples (and ichnospecies) must be assessed accordingly.

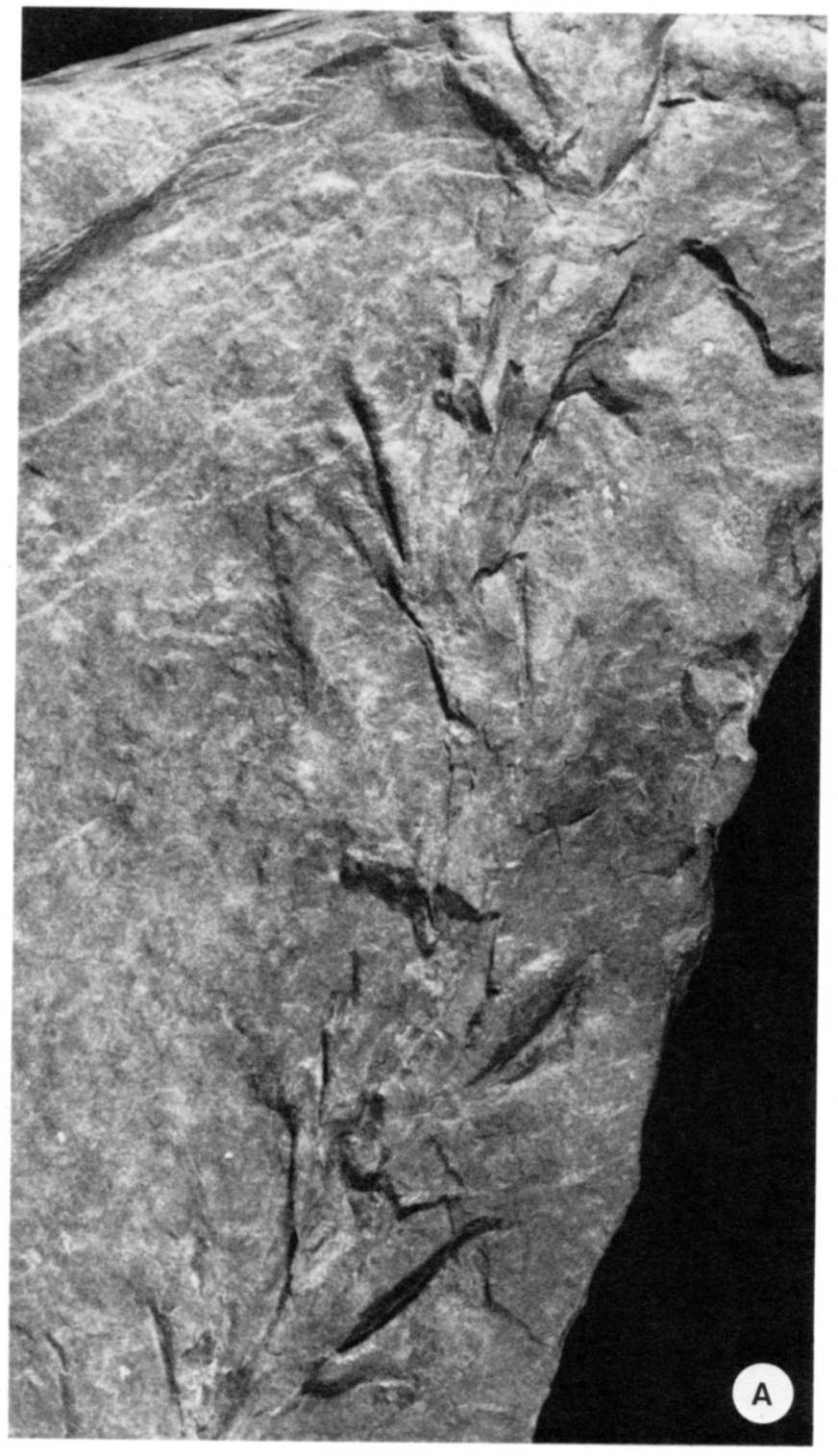

Historically, Phycodes was believed to be a reliable indicator of shallow water marine conditions and a characteristic trace fossil of the Cruziana ichnofacies of Seilacher (1964), occurring in low-energy environments with relatively stable substrates. However, more recently it has since been reported from nonmarine (Pollard, 1985; Buatois and Mángano, 1990), brackish (Hakes, 1985; Greb and Chesnut, 1992) and deep water (Crimes et al., 1977, 1981; Bradley, 1981; Narbonne, 1984; this study) deposits. It ranges in age from Cambrian (Crimes and Anderson, 1985) to Miocene (Bradley, 1981).

\section{Phycodes templus isp. nov.}

Figures 2 to 4

? Trail of unknown affinity; Rodriguez and Gutschick, 1970, page 436 , plate 10 , figure $\mathrm{C}$.

Type material: Holotype NBMG 9202 (Fig. 2A); paratypes NBMG 9203-NBMG 9209 (Figs. 2B, C; 3A-E; 4A-C).
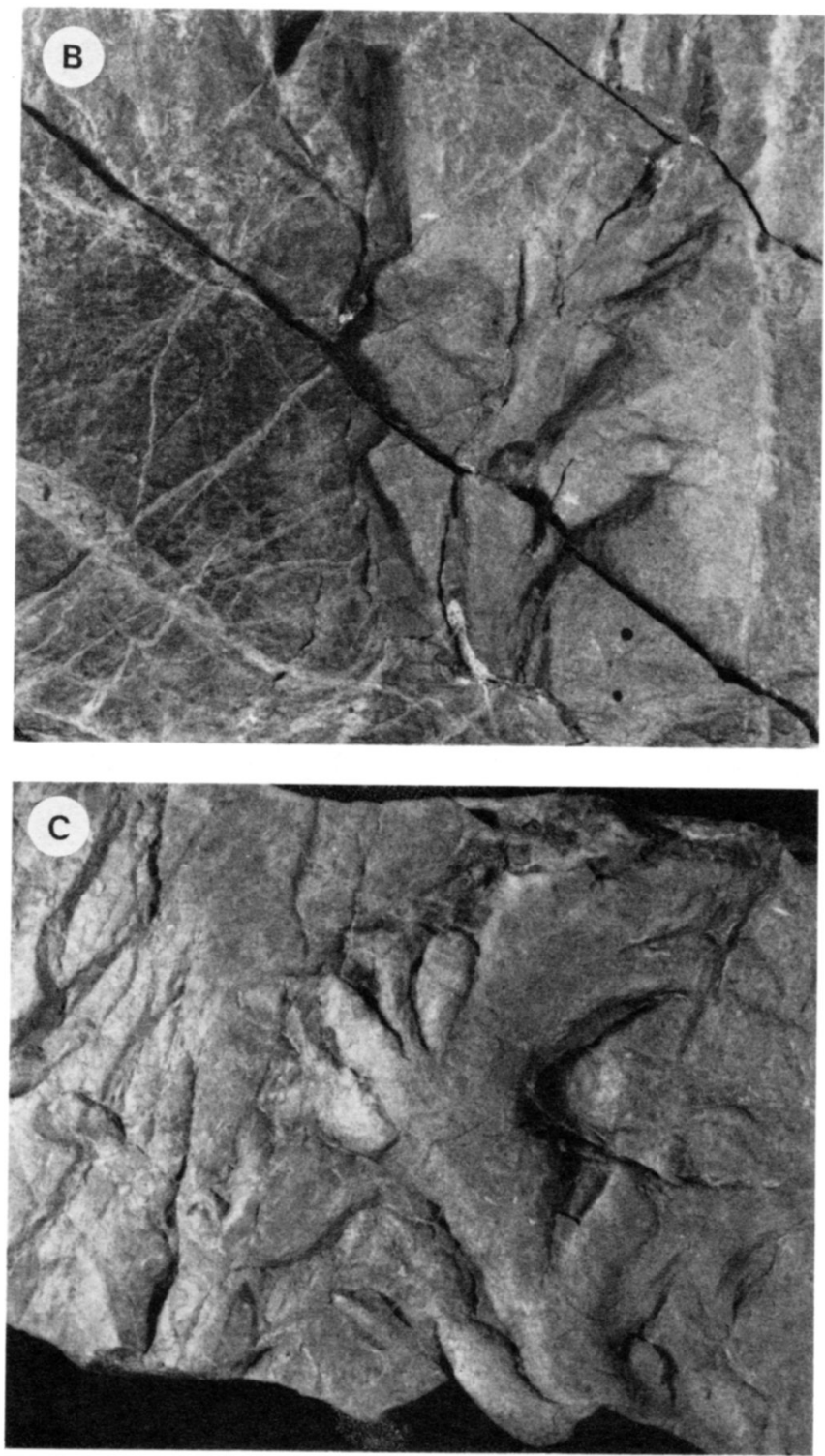

Fig. 2. (A) Holotype of $P$. templus, NBMG 9202, x 0.94. (B) Paratype NBMG 9205, x 0.72. (C) Paratype NBMG 9204, $x$ 0.86, also enlarged in Figure 3C. Preservation is in convex hyporelief. 

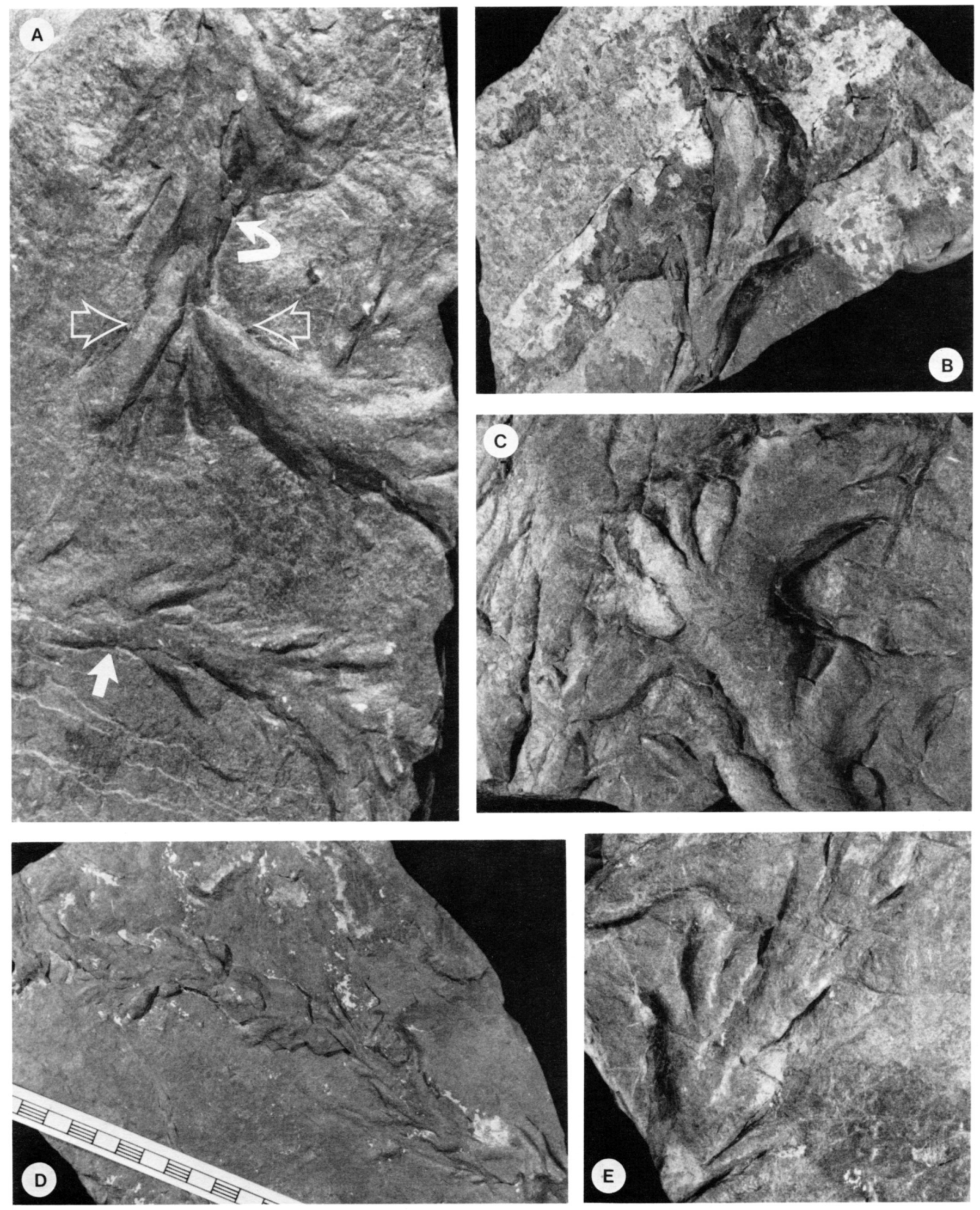

Fig. 3. Paratypes of $P$. temiplus. (A) Paratypes NBMG 9206, $\times 1.17$ (curved solid arrow) and NBMG 9207, $\times 1.17$ (short solid arrow). Open arrows indicate position of vertical section through NBMG 9206 as illustrated in Figure 4A and C. (B) Paratype NBMG 9203, x 0.76. (C) Paratype NBMG 9204, x 1.06 (see also Fig. 3C). (D) Paratype NI3MG 9209, centimetre scale. (E) Paratype NBMG 9208, x 0.81. Preservation of all material is in convex hyporelief. 
Material: 13 specimens collected, 8 deposited in the Division of Natural Sciences, Saint John Museum, New Brunswick, Canada, with repository numbers NBMG 9202 - NBMG 9209 inclusive; remaining material located in collections in the Department of Geology, University of New Brunswick.

Etymology: Templum (Latin equivalent of pagoda) reflecting the inverted pagoda-like appearance of individual structures.

Location: Roadcuts on Route 385, 22 to $26 \mathrm{~km}$ northeast of the village of Riley Brook, Victoria County, northwestern New Brunswick, Canada (Fig. 1). NBMG 9204, Location 1, Lat. $47^{\circ} 18.4^{\prime} \mathrm{N}$, Long. $67^{\circ} 2.4^{\prime} \mathrm{W}$; NBMG 9202 - NBMG 9203, Location 2, Lat. $47^{\circ} 19.7^{\prime} \mathrm{N}$, Long. $67^{\circ} 1.8^{\prime} \mathrm{W}$; NBMG 9205 NBMG 9207, Location 3, Lat. $47^{\circ} 19.8^{\prime} \mathrm{N}$, Long. $67^{\circ} 1.6^{\prime} \mathrm{W}$; NBMG 9208 - NBMG 9209, Location 4, Lat. 47²0.2'N, Long. $67^{\circ} 1.4^{\prime} \mathrm{W}$.

Age: The Wapske Formation of the Tobique Group is regarded as Helderbergian (Early Devonian) in age (St. Peter, 1978, 1979; Wilson, 1990).

Diagnosis: Phycodes possessing two or, more typically, several horizontally interconnected broomlike or flabellate bundles that collectively form an inverted pagoda-like structure.

Description: Specimens are preserved as convex hyporclicf expressions of endorelief burrow systems on the soles of 26 to 53 $\mathrm{mm}$ thick, grey, argillaceous, micaceous, parallcl-laminated siltstone and fine-grained sandstone. Single specimens possess a minimum of 2 , typically more (up to 5), sets of broomlike or flabellate bundles of burrows, individual bundle sets each interconnecting horizontally, either straightly (e.g., Fig. 2A) or obliquely (e.g., Fig. 3A), and collectively forming inverted pagoda-shaped structures.

Single broomlike or flabcllate bundle scts, each 16 to 45 $\mathrm{mm}$ wide, consist of 3 to 7 burrows that are individually essentially straight, more rarely slightly curved, and smooth or covered with delicate wartlike structures. Vertical sectioning of selected sets indicates that individual burrows within a set are typically not vertically tiered to any great cxtent (Fig. 4). Instead, each set comprises variably elliptical burrows that were apparently only produced, along a single sand-mud interface, but at slightly different levels, and were clearly post-depositional in origin. The primary cross-sectional shape of the individual burrows is difficult to ascertain as a result of primary compaction and subsequent deformation. Individual burrows within a single set are 3 to $9 \mathrm{~mm}$ wide and 12 to $45 \mathrm{~mm}$ long, burrow width typically increasing distally. Single burrows within

Fig. 4. (A) Vertical section and accompanying sketch of paratype NBMG 9206 of $P$. templus illustrating elliptical lined burrows that do not exhibit well-developed vertical ticrs. This vicw is taken looking directly above the open arrows indicated in Figure $3 \mathrm{~A}, \times 3.65$. (B) Vertical sketch of the presumed initial proximal burrow of paratype NBMG 9204 of $P$. templus, as illustrated in Figures 2C and 3C, cxhibiting well-developed mudstone lining, $\times 4.3$. (C) Vertical section and accompanying sketch of paratype NBMG 9206 of $P$. templus directly below the open arrows indicated in Figure 3A, $\times 2.01$.
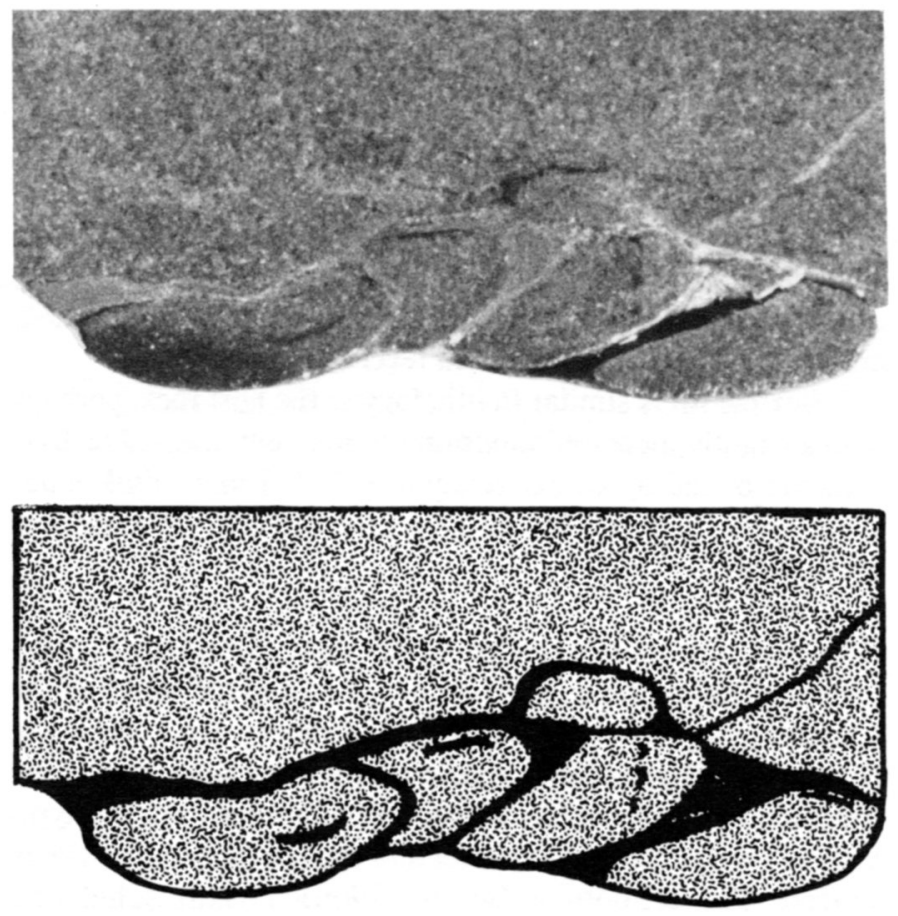

A
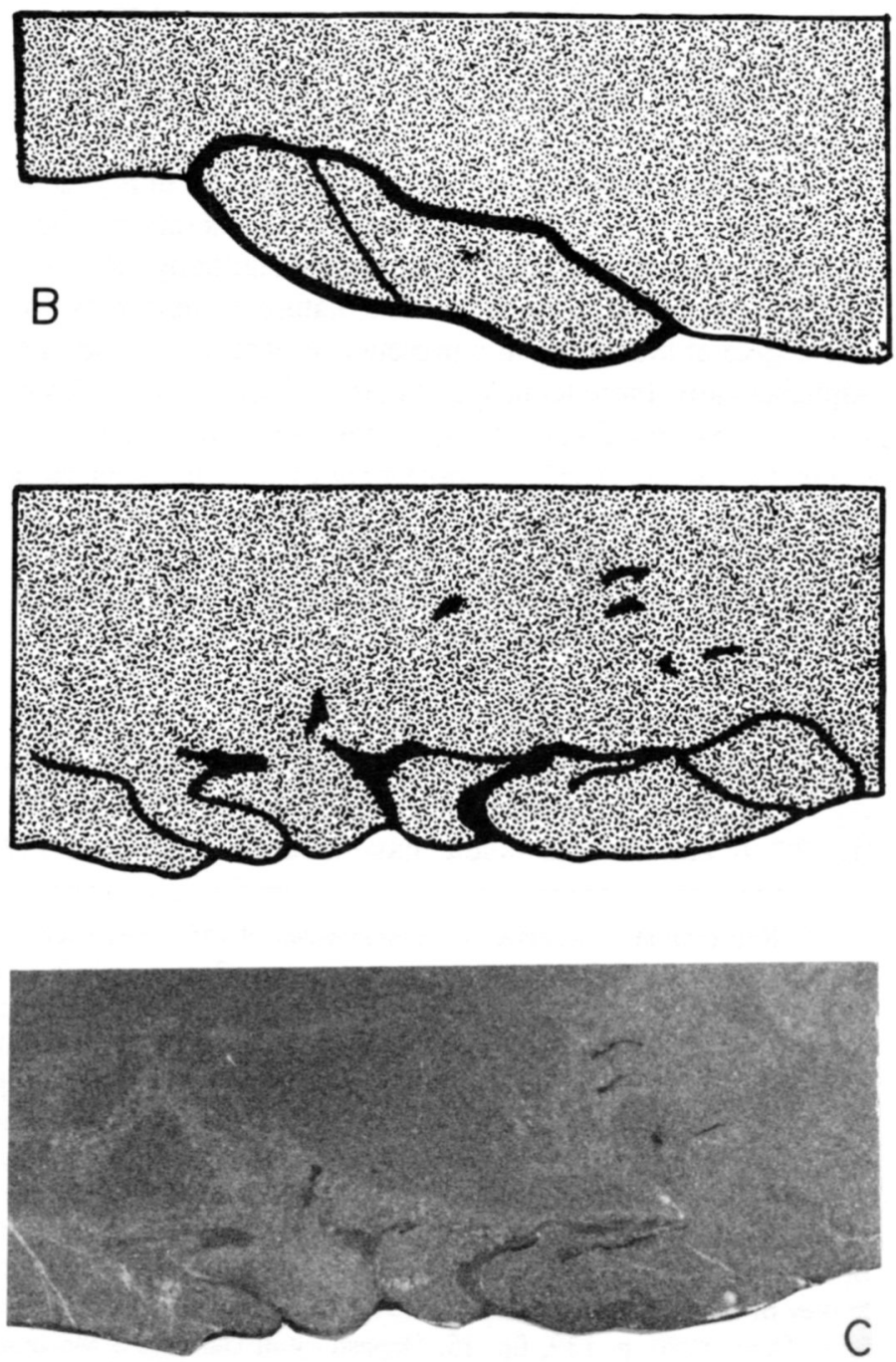
a set may or may not vary in length and width. Burrows in individual sets initiate at a single point of origin, subsequent sets initiating from the distal end of a single burrow of the previously established set. Individual sets may or, more commonly, may not overlap. In some instances individual burrows within a single set may bifurcate, although this is uncommon. Typically, interconnected sets occur on the same surface; however, in one example the individual sets, although interconnected, are clearly on a slightly different level of stratification.

Burrow fill is similar in lithology to the host rock, perhaps with a slightly increased mudstone component; individual burrows are bound by an extremely thin $(<0.5 \mathrm{~mm})$, dark mudstone lining (Fig. 4). No spreiten or other internal structures are present.

Remarks: The closely spaced tunnel systems arranged in discrete sets differentiate Phycodes templus from the superficially similar ichnogenus Chondrites von Sternberg, the latter being characterized by generally systematically branching, commonly dendritic systems, within which individual burrows are typically of much narrower diameter and considerably more widcly spaced. The ichnotaxa Dendrotichnium Häntzschel and Dendrorhaphe Seilacher also exhibit multiple branches from a single stem, but in both, the branches are not arranged in sets and the overall form of the burrow system markedly differs from the material described herein (see Häntzschel, 1975; Seilacher, 1977). Thus, the burrows described herein can clearly be assigned to Phycodes.

To our knowledge, 15 additional ichnospecies of Phycodes have been named and, or, described in the literature. These ichnospecies were individually distinguished utilizing such characteristics as overall pattern and size, nature, style, disposition and degree of branching and presence or absence of a spreite. Alphabetically, these ichnospecies are: $P$.? antecedens Webby, 1970; P. auduni Dam, 1990; P. bromleyi Dam, 1990; P. circinatus Richter, 1853; $P$. coronatum Crimes and Anderson, 1985; P. curvipalmatum Pollard, 1981; P. flabellus (Miller and Dyer, 1878); $P$. gregarius Chiplonkar and Badve, 1969; $P$. harlani (Hall, 1843); P.? initium Webby, 1970; P. palmatus (Hall, 1852); P. pedum Seilacher, 1955; P. reniforme Hofmann, 1979; $P$. ungulatus Fillion and Pickerill, 1990; and $P$. wabanensis Fillion and Pickerill, 1990 (Fig. 5).

Of these, P.? initium Webby, 1970 is a nomen nudum, having been utilized only in a plate caption (Webby, 1970, p. 102, fig. 20, A and B) that should have actually referred to $P$. ? antecedens as described in the main text of his paper. Apart from the presence on $P$ ? antecedens of oblique grooves on the primary burrow adjacent to each side branch, we do note that it is otherwise virtually morphologically identical to and could be considered a preservational variant and hence a junior synonym of $P$. pedum. Additionally, $P$. gregarius Chiplonkar and Badve, 1969, being described as Phycocodes gregarius, is a lapsus calamni. As this ichnospecies was formulated from a single specimen and differentiated as such merely on the basis of its small size, it is best regarded as a nomen dubium (cf. Pickerill, 1994). Although the quality of the figure is extremely poor, it appears to most closely resemble $P$. circinatus.

We also note that there is still confusion taxonomically with respect to three additional ichnospecies, namely $P$. harlani (Hall, 1843), P. Jabellus (Miller and Dyer, 1878) and P. wabanaensis Fillion and Pickerill, 1990. Seilacher (1955) expanded the morphological limits of Phycodes and in doing so regarded Arthrophycus Hall, 1852 as a junior synonym. Most subsequent authors, however, have distinguished these two ichnotaxa (e.g., Häntzschel, 1962, 1975; Osgood, 1970; Pickerill et al., 1991). Herein we follow the suggestion of these latter authors. Thus $P$. harlani (Hall, 1843) should more appropriately be regarded as A. harlani Hall, 1852, considered by Häntzschel $(1962,1975)$ as the nomenclatural type. A more detailed discussion on the relationships of these ichnotaxa is given in Osgood (1970). $P$. flabellus, originally described by Miller and Dyer (1878) as Lichrophycus flabellum, is also characterized by distinctive transverse annulations and possibly could therefore also be regarded as an ichnospecies of Arthrophycus. A re-examination of the type is clearly warranted, and for now we regard it as of uncertain status. $P$. wabanaensis was erected by Fillion and Pickerill (1990, p. 48) for “...Phycodes, in which a master tunnel branches at a very acute angle to form a broomlike burrow system. Proximal tube may be absent. Distal portion may also be composed of coalescent, nearly parallel, successive, retrusive, teichichnid burrows that are offset to the side...." This diagnosis corresponds closely to that of the ichnotaxon Caugichnus Hofmann, 1979, except that in the latter there is no master tunnel and instead it is characterized by multiple-entry systems. Additionally, Caugichnus possesses both protrusive and retrusive spreiten. We therefore regard $P$. wabanaensis and Caugichnus as distinctive and separate ichnotaxa.

Specimens from the Wapske Formation clearly represent a new ichnospecies of Phycodes. Individual burrow systems comprise 2 to 5 bundled sets that each branch horizontally in a

Fig. 5. Representative sketches of ichnospecies of Phycodes Richter, 1850. For those ichnospecies previously named in the literature but not figured here see text for details. (1) P. coronatum Crimes and Anderson, x 0.75 (to the left), $x 1.55$ (to the right) (after Crimes and Anderson, 1985, p. 329, figs. 11.1,3. Depository in Geological Survey of Canada, holotype GSC 73340). (2) P.? antecedens Webby, $x 1.43$ (after Webby, 1970, p. 102, fig. 20B. Depository in Palaeontological Collection of the Department of Geology and Geophysics, University of Sydney, paratype SUP 19895). (3) P. pedum Seilacher, x 0.72 (after Seilacher, 1955, pl. 25, fig. 3. Depository in Geologischen Instituts, Tübingen, holotype IC 1071/31). (4) P. ungulatus Fillion and Pickerill, x 1.43 (after Fillion and Pickerill, 1990, p. 105, pl. 11, fig. 18. Depository in Geological Survey of Canada, holotype GSC 78188). (5) P. curvipalmatum Pollard, x 1.10 (after Pollard, 1981, p. 576, text-figs. 7a,b. Depository in special collections, Geology Department, University of Manchester, holotype MGSF32). (6) Holotype of P. templus Han and Pickerill, $x$ 0.50 (NBMG 9202). (7) P. auduni Dam, x 0.97 (after Dam, 1990, p. 136, fig. 13C. Depository in Geological Museum, University of Copenhagen, holotype MGUH 19628). (8) P. wabanaensis Fillion and Pickerill, x 1.00 (after Fillion and Pickerill, 1990, p. 105, pl. 11, fig. 19. Depository in Geological Survey of Canada, holotype GSC 78198). (9) $P$. circinatus Richter, x 0.49 (after Seilacher, 1955, p. 385, fig. 3b). (10) $P$. bromleyi Dam, x 0.49 (after Dam, 1990, p. 139, fig. 15. Depository in Geological Museum, University of Copenhagen, holotype MGUH 19627). (11) P. reniforme Hofmann, x 0.67 (after Hofmann, 1979, p. 48, fig. 9. Depository in Geological Survey of Canada, holotype GSC 54213). (12) P. palmatus Hall, no scale (after Hall, 1852, pl. 6, fig. 1. Depository in New York State Collection without number). 


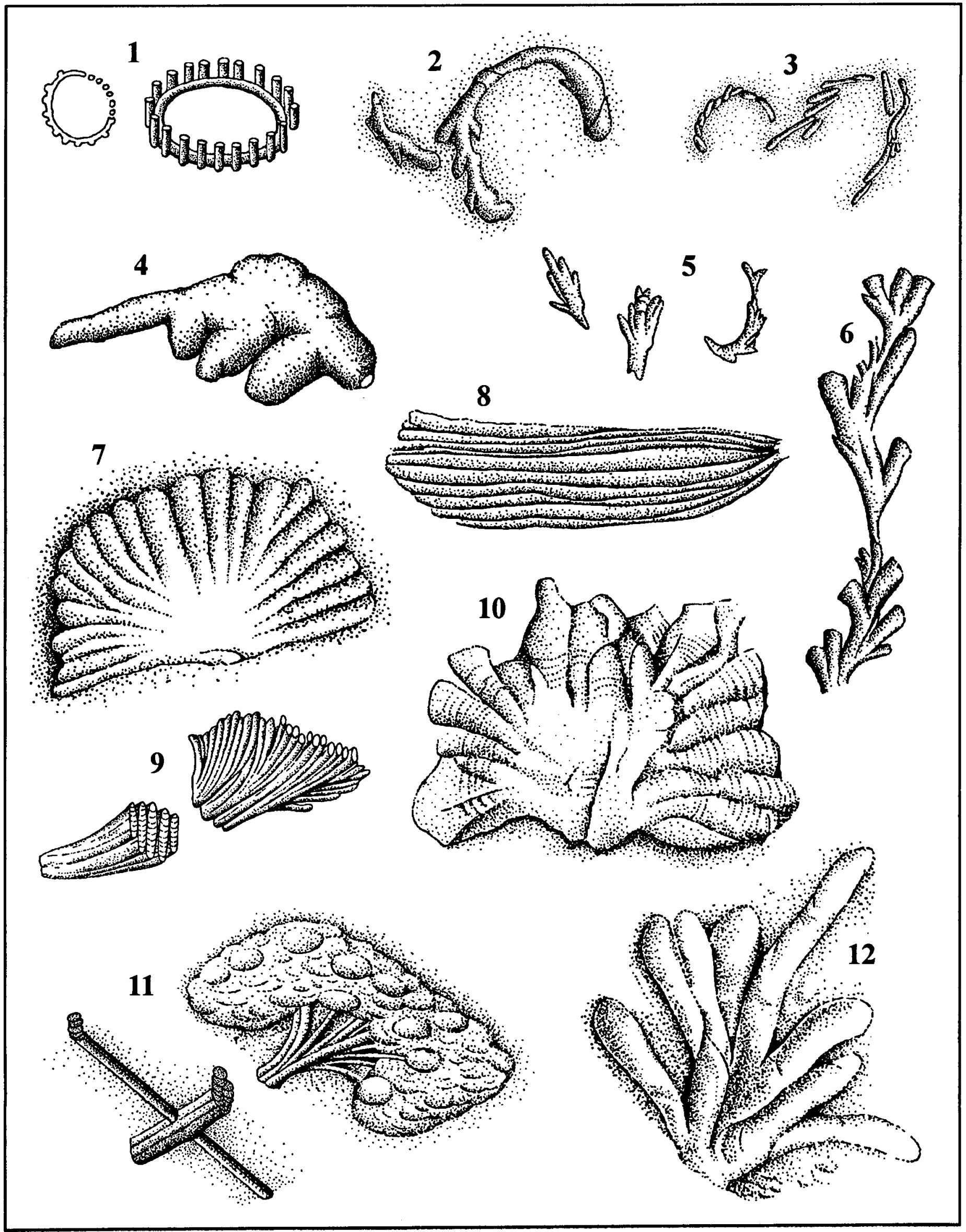


broomlike or flabellate fashion, thereby collectively forming an interconnected or slightly overlapping inverted pagoda-shaped outline. Although in some specimens this inverted pagodashaped outline is not particularly obvious, such examples do exhibit several broomlike bundles arranged along the main stem. This characteristic is radically different from most other previously described ichnospecies of Phycodes, several of which, namely $P$. auduni, $P$. bromleyi, $P$. circinatus, $P$. flabellus, $P$. palmatus, $P$. reniforme, $P$. ungulatus and $P$. wabanensis, typically exhibit only one discrete set of bundled burrows emanating from the proximal tunnels (Fig. 5). The presence of interconnected bundled sets characteristic of $P$. templus clearly differentiates it from these latter ichnospecies.

Superficially, specimens from the Wapske Formation most closely resemble the interwoven burrow network of $P$. curvipalmatum (Pollard, 1981, pl. 89, figs. 1-2, text-fig. 7e), but exhibit the following differences: (1) individual burrows and burrow sets in $P$. templus are larger; (2) the entire burrow systems in $P$. templus are larger; (3) $P$. templus has regular, systematically branched sets which exhibit a broomlike or flabellate form, whereas in $P$. curvipalmatum the branches are dichotomous or palmate; (4) the tunnels of $P$. templus branch out at acute angles from a center and only rarely bifurcate, while in $P$. curvipalmatum the interbranch angle, while mostly acute, can be up to $90^{\circ}$, and the tunnels mostly bifurcate; and (5) the tunnels of $P$. templus are essentially straight and increase in width distally while the tunnels in $P$. curvipalmatum are curved and taper outward.

Finally, $P$. templus differs from $P$. pedum by possessing several tunnels within a single bundled set. $P$. pedum is characterized by single burrows periodically branching on one or both sides of the master tunnel, the branches never being arranged in discrete sets. In comparison to P.? antecedens, P. templus also exhibits bundled sets, a feature not present in the former ichnotaxon; additionally $P$. templus is considerably larger. The remaining ichnospecies, $P$. coronatum, is characterized by a circular burrow outline with vertical (and themselves unbranched) offshoots from the outer margin of the circle (Crimes and Anderson, 1985); it clearly differs from $P$. templus as described herein.

The only possible additional occurrence of $P$. templus was reported from shallow marine Mississippian strata of western Montana (Rodriguez and Gutschick, 1970, p. 436, pl. 10, fig. c). This specimen was documented as a trail of unknown affinity, possibly Phycodes. Although the branching angles of its tunnels are more acute than those in material from the Wapske Formation, we tentatively regard the specimen as conspecific. Narbonne (1981, p. 210) considered Rodriguez and Gutschick's (1970) specimen as synonymous with Uchirites Macsotay, 1967. However, in his original description, Macsotay (1967) made no reference to branching within Uchirites; indeed, none of his figured specimens illustrates branching. We therefore believe that the aforementioned specimen as more akin to Phycodes, particularly $P$. templus, though only include it as a tentative synonym pending examination of the specimen.

As with the interpretation of most previously documented ichnospecies of Phycodes (see previous references), worm-like organisms or possibly even arthropods were presumably responsible for the burrow systems. In view of the absence of external ornament on the burrow walls of $P$. templus, worm-like organ- isms are most favoured. Interestingly, the presence in $P$. templus of a distinct mudstone lining (sensu Keighley and Pickerill, 1994) and a structureless fill does not immediately invite comparison of it having been produced by a deposit feeder, the traditional interpretation of Phycodes (e.g., Seilacher, 1955; Marintsch and Finks, 1982). More typically, deposit-feeding burrows, commonly being actively filled, contain some form of internal structuring (e.g., menisci) or faecal material produced by biological processing by the causative organism. In contrast, passively filled, formerly open burrow structures typically contain a massive and unstructured internal fill and, depending upon the geotechnical properties of the substrate at the time of production, will normally be lined (Bromley, 1990). However, of particular relevance are present-day examples of deposit-feeding polychaetes that secrete abundant mucous and produce actively filled, lined burrows (Schäfer, 1972; Aller, 1983). We envisage $P$. templus to have been produced in a similar fashion, that is, as a lined structure produced by a vagile deposit feeder. Given such an interpretation, the absence of any obvious internal structures within $P$. templus is enigmatic. Notably, however, all the material is preserved in positive hyporelief with only the external walls of individual burrows being exposed; no horizontally truncated material, that would reveal the nature of the burrow interior, is present in the collections. Thus, although transverse and longitudinal vertical sectioning and etching of several specimens failed to reveal any internal fabrics, it may be that an internal structure is present but is too subtle to discern, requiring natural weathering processes of truncated material to demonstrate its presence or otherwise.

\section{ACKNOWLEDGEMENTS}

We wish to thank A. Gómez, R. McCulloch and D. Campbell for technical assistance in all phases of the preparation of this manuscript. Reg Wilson and Les Fyffe, under the auspices of the New Brunswick Department of Natural Resources and Energy, assisted in defraying fieldwork expenses. Randy Miller provided repository numbers for the New Brunswick Museum, and Chris Stanley and Dave Keighley reviewed an initial version of the manuscript. We appreciate the constructive reviews provided by journal reviewers Hans Hofmann and Guy Narbonne. Financial support was provided by a Natural Sciences and Engineering Council of Canada operating grant to RKP, which is gratefully acknowledged.

ALLER, R.C. 1983. The importance of the diffuse permeability of animal burrow linings in determining marine sediment chemistry. Journal of Marine Research, 41, pp. 299-322.

Bradley, J. 1980. Scolicia and Phycodes, trace fossils of Renilla (Pennatulacea). Pacific Geology, 14, pp. 73-86.

1981. Radionereites, Chondrites and Phycodes; trace fossils of anthoptiloid sea pens. Pacific Geology, 15, pp. 1-16.

Bromley, R.G. 1990. Trace Fossils, Biology and Taphonomy. Unwin Hyman, London, 280 p.

Buatols, L.A. and MÁngano, M.G. 1990. Una Asóciacion de trazas fosiles del Carbonico Lacustre del area de Los Jumes, Catamarca, Argentina: su comparacion con La icnofacies de Scoyenia. V Congreso Argentino de Paleontologia y Bioestratigrafia, 1, pp. 77-81. 
Chiplonkar, G.W. and Badve, R.M. 1969. Trace fossils from the Bagh Beds. Journal of the Palaeontological Society of India, 14, pp. 110 (published in 1970).

Crimes, T.P. and Anderson, M.M. 1985. Trace fossils from Late Precambrian-Early Cambrian of southeastern Newfoundland (Canada): temporal and environmental implications. Journal of Paleontology, 59, pp. 310-343.

Crimes, T.P., LegG, I., Marcos, A., and Arboleya, M. 1977. ?Late Precambrian-low Lower Cambrian trace fossils from Spain. In Trace fossils 2. Edited by T.P. Crimes and J.C. Harper. Geological Journal, Special Issue 9, Seel House Press, Liverpool, pp. 91-138.

Crimes, T.P., Goldring, R., Homewood, P., Stuijvenberg, J. Van, and WinkLer, W. 1981. Trace fossil assemblages of deep-sea fan deposits, Gurnigel and Schlieren flysch (Cretaceous-Eocene), Switzerland. Eclogae Geologicae Helvetiae, 74, pp. 953-995.

DAM, G. 1990. Taxonomy of trace fossils from the shallow marine Lower Jurassic Neill Klinter Formation, East Greenland. Bulletin of the Geological Society of Denmark, 38, pp. 119-144.

Dostal, J., WILSON, R.A., and KePPIE, J.D. 1989. Geochemistry of SiluroDevonian Tobique volcanic belt in northern and central New Brunswick (Canada): tectonic implications. Canadian Journal of Earth Sciences, 26, pp. 1282-1296.

Fillion, D. and Pickerill, R.K. 1990. Ichnology of the Cambrian? to Lower Ordovician Bell Island and Wabana groups of eastern Newfoundland, Canada. Palaeontographica Canadiana, 7, 119 p.

Greb, S.F. and Chesnur, D.R., Jr. 1992. Transgressive channcl filling in the Breathitt Formation (Upper Carboniferous), Eastern Kentucky Coal Field, USA. Sedimentary Geology, 5, pp. 209-221.

Hakes, W.G. 1985. Trace fossils from brackish-marine shales, Upper Pennsylvanian of Kansas, U.S.A. In Biogenic structures: their use in interpreting depositional environments. Edited by H.A. Curran. Society of Economic Paleontologists and Mineralogists, Special Publication, 35, pp. 21-35

HALL, J. 1843. Geology of New York. Part 4. Survey of the Fourth Geological District. Carroll and Cook, Albany, 683 p.

1852. Palaeontology of New York. Volume II. Containing descriptions of the organic remains of the Lower Middle Division of the New York System, (equivalent in part to the Middle Silurian rocks of Europe). C. van Benthuysen, Albany, $362 \mathrm{p}$.

HÄntzschel, W. 1962. Trace fossils and problematica. In Treatisc on Invertebrate Paleontology, Part W, Misccllanea. Edited by R.C. Moore. Geological Society of America and University of Kansas Press, New York and Lawrence, Kansas, pp. W177-W245.

1975. Trace fossils and problematica. In Treatise on Invertebrate Paleontology, Part W, Miscellanea, Supplement I. Edited by C. Teichert. Geological Society of America and University of Kansas Press, Boulder, Colorado and Lawrence, Kansas, pp. WIW269.

Hofmann, H.J. 1979. Chazy (Middle Ordovician) trace fossils in the Ottawa-St. Lawrence Lowlands. Bulletin of the Geological Survey of Canada, 321, pp. 27-59.

International Commission on Zoological Nomenclature 1985. International Code of Zoological Nomenclature. Third edition adopted by the Twentieth General Assembly of the International Union of Biological Sciences, February 1985. Edited by W.D.L. Ride, C.W. Sabrosky, G. Bernardi and R.V. Melville. International Trust for Zoological Nomenclature in association with British Museum (Natural History), London and University of California Press, Berkeley and Los Angeles, $338 \mathrm{p}$.

Keighley, D.G. and Pickerill, R.K. 1994 (in press). The ichnogenus Beaconites and its distinction from Ancorichmus and Taenidium. Palaeontology, 37.

Macsotay, O. 1967. Huellas problemáticas y su valor palcoecológico en Venezuela. Geos (Venezuela), 16, pp. 7-79.

Māgdefrau, K. 1934. Uber Phycodes circinalum Reinh. Richter aus dem thüringischen Ordovicium. Neues Jahrbuch für Mineralogie, Geologie und Paläontologie, Beilage-Bände, 72, pp. 259-282.

Marintsch, E.J. and Finks, R.M. 1982. Lower Devonian ichnofacies at Highland Mills, New York and their gradual replacement across environmental gradients. Journal of Paleontology, 56, pp. 10501078.

Miller, S.A. and DyER, C.B. 1878. Contributions to paleontology. Journal of the Cincinnati Society of Natural History, 1, pp. 24-40.

Narbonne, G.M. 1981. Stratigraphy, reef development and trace fossils of the Upper Silurian Duoro Formation in the southeastern Canadian Arctic islands. Unpublished Ph.D. dissertation, University of Ottawa, $259 \mathrm{p}$.

- 1984. Trace fossils in Upper Silurian tidal flat to basin slope carbonates of Arctic Canada. Journal of Paleontology, 58, pp. 398415.

Osgood, R.G., JR. 1970. Trace fossils of the Cincinnati area. Palaeontographica Americana, 6, pp. 277-444.

PICKERILL, R.K. 1986. Stratigraphy, sedimentology and structural analysis of the geology of the Tobique Reserve Lands with an economic assessment of its geologic resources. Unpublished Report to the Department of Indian and Northern Affairs, Ottawa, Ontario, $61 \mathrm{p}$.

1991. The trace fossil Neonereiles multiserialis Pickerill and Harland, 1988 from the Devonian Wapske Formation, northwest New Brunswick. Atlantic Geology, 27, pp. 119-126.

1994. Nomenclature and taxonomy of invertebrate trace fossils. In The Palaeobiology of Trace Fossils. Edited by S.K. Donovan. John Wiley and Sons, Chichester, pp. 3-42.

Pickerill, R.K., Flllion, D., and Brenchley, P.J. 1991. A note on the occurrence of Arthrophycus in the Bell Island Group of eastern Newfoundland. Atlantic Geology, 27, pp. 73-77.

Pollard, J.E. 1981. A comparison between the Triassic trace fossils of Cheshire and South Germany. Palaeontology, 24, pp. 555-588.

- 1985. Evidence from trace fossils. In Evolution and environment in the Late Silurian and Early Devonian. Edited by W.G. Chaloner and J.D. Lawson. Royal Society of London Philosophical Transactions, B309, pp. 241-242.

Richter, R. 1850. Aus der thüringischen Grauwacke. Deutsche Geologische Gesellschaft, Zeitschrift, 2, pp. 198-206.

1853. Gaea von Salfeld. Programm d. Realsch. Saalfeld, pp. 3-32.

Rodriguez, J. and Gutschick, R.C. 1970. Late Devonian-Early Mississippian ichnofossils from western Montana and northern Utah. In Trace fossils. Edited by T.P. Crimes and J.C. Harper. Geological Journal, Special Issue 3, Seel House Press, Liverpool, pp. $407-438$.

SCHÄFER, W. 1972. Ecology and palaeoecology of marine environments. Oliver and Boyd, and University of Chicago Press, Edinburgh and Chicago, $568 \mathrm{p}$.

Sellacher, A. 1955. 5. Spuren und Fazies im Unterkambrium. In Beiträge zur Kenntnis des Kambriums in der Salt Range (Pakistan). Ediled by O.H. Schindewolf and A. Seilacher. Akademie der Wissenschaften und der Literatur zu Mainz, mathematischnaturwissen-schaftliche Klasse, Abhandlungen, 10, pp. 373-399. 1964. Biogenic sedimentary structures. In Approaches to paleoecology. Edited by J. Imbrie and N. Newell. John Wiley, New York, pp. 296-316.

1977. Pattern analysis of Paleodictyon and related trace fossils. In Trace fossils 2. Ediled by T.P. Crimes and J.C. Harper. Geological Journal, Special Issue 9, Seel House Press, Liverpool, pp. 289-334.

St. Peter, C. 1978. Geology of head of Wapske River, map area J-B (21 J/14). New Brunswick Natural Resources, Mineral Resources Branch, Map Report 78-1, 24 p.

1979. Geology of Wapske-Odell River Arthurette Region, New 
Brunswick map areas I-13, I-14, H-14 (parts of $21 \mathrm{~J} / 11,21 \mathrm{~J} / 12$, $21 \mathrm{~J} / 13,21 \mathrm{~J} / 14$ ). New Brunswick Natural Resources, Mineral Resources Branch, Map Report 79-2, 32 p.

WebBy, B.D. 1970. Late Precambrian trace fossils from New South Wales. Lethaia, 3, pp. 79-109.
WiLson, R.A. 1990. Geology of New Denmark-Salmon River area Victoria County, New Brunswick (parts of NTS J/13, $21 \mathrm{~J} / 14,21$ O/3, 21 O/4). New Brunswick Department of Natural Resources, Minerals and Energy Division, Report of Investigation 23, 67 p. 